\title{
Influence of the duration of antiretroviral use on insulin resistance among people living with HIV with lipodystrophy
}

\author{
Influência do tempo de uso de Antirretrovirais na resistência insulínica entre \\ pessoas vivendo com HIV com síndrome lipodistrófica
}

Thiago Rodrigues Faria Vitorazzi ${ }^{1}$, Taila Santos de Freitas ${ }^{2}$, Loiane Sartori Oliveira ${ }^{1}$, Anderson Marliere Navarro ${ }^{1}$

\begin{abstract}
Objective: The present study evaluated the influence of the duration of antiretroviral therapy on insulin resistance among people living with HIV with lipodystrophic syndrome.

Methods: The study assessed 36 subjects of both sexes between 22 and 60 years old split into three groups: 1) HIV-positive using antiretroviral with lipodystrophy syndrome $(\mathrm{HIV}+\mathrm{LIPO}+) ; 2)$ HIV-positive using antiretroviral therapy with no lipodystrophy syndrome (HIV+LIPO-); and 3) HIV-negative and healthy (Control). The data were collected at the Special Unit for the Treatment of Infectious Diseases (Unidade Especial de Tratamento para Doenças Infecciosas - UETDI) of the Dyslipidemia Outpatient Clinic (Ambulatório de Dislipidemia - ADIS) of the General Hospital of the Medical School of Ribeirão Preto (HC-FMRP). The biochemical assessment used laboratory kits when the results were not available in the volunteer's records.

Results: Higher HOMA-IR values were observed for the group 1: HIV+LIPO+ $(1,61 \pm 1,17)$ compared to group 2: HIV+LIPO- $(0,79 \pm 0,87)$ and group 3: Control $(0,46 \pm 0,72)$ and such values were positively correlated with the time of antiretroviral medication use $(r=0,41)$.

Conclusions: The time of infection by HIV and the use of antiretrovirals impact the glucose metabolism with changes in serum insulin levels and consequent insulin resistance and increased risk for the development of diabetes and diseases related to carbohydrate metabolism.
\end{abstract}

Keywords: HIV. Lipodystrophy. Insulin Resistance. Antiretroviral Therapy.

\section{RESUMO}

Objetivo: O presente estudo avaliou a influência do tempo de uso de antirretrovirais na resistência insulínica (HOMA-IR) entre pacientes vivendo com HIV, com síndrome lipodistrófica.

1. Departamento de Clínica Médica - FMRP/USP, Ribeirão Preto, São Paulo, Brasil.

2. Departamento de Alimentos e Nutrição, Faculdade de Ciências Farmacêuticas de Araraquara, São Paulo Universidade Estadual "Júlio de Mesquita Filho" UNESP, Campus de Araraquara, São Paulo, Brazil.
CORRESPONDÊNCIA:

Loiane Sartori Oliveira. Hospital das Clínicas da Faculdade de Medicina de Ribeirão Preto da Universidade de São Paulo Departamento de Clínica Médica Campus Universitário s/n - Monte Alegre 14048-900 - Ribeirão Preto - SP

Recebido em 16/11/2017

Aprovado em 24/10/2018 
Métodos: Foram avaliados 36 indivíduos de ambos os sexos, com idade entre 22 e 60 anos, divididos em três grupos: 1) Soropositivo para HIV em uso de TARV com síndrome de lipodistrofia $(\mathrm{VIH}+\mathrm{LIPO}+)$; 2) Soropositivo para HIV em uso de TARV sem síndrome de lipodistrofia (VIH + LIPO-); 3) Soronegativo para HIV (Controle). Os dados foram coletados na Unidade Especial de Tratamento para Doenças Infecciosas (UETDI), no Ambulatório de Dislipidemia (ADIS) do Hospital das Clínicas da Faculdade de Medicina de Ribeirão Preto (HC-FMRP). Para a análise bioquímica foram utilizados kits de laboratório, quando os mesmos não estavam disponíveis nos prontuário eletrônico.

Resultados: Foram observados maiores valores de HOMA-IR para o grupo GRUPO 1: HIV+LIPO+ $(1,61 \pm 1,17)$, comparado aos grupos GRUPO 2: HIV+LIPO- $(0,79 \pm 0,87)$ e GRUPO 3: Controle $(0,46 \pm 0,72)$, sendo que o HOMA-IR apresentou correlação positiva com o tempo de uso dos antirretrovirais $(r=0,41)$.

Conclusão: O tempo de infecção por HIV e o uso de antirretrovirais influenciam o metabolismo glicídico, com modificações nos níveis séricos de insulina e consequentemente resistência à insulina e maior risco para desenvolver diabetes e enfermidades relacionadas ao metabolismo de carboidratos.

Palavras chave: HIV. Lipodistrofia. Resistência à Insulina. Terapia Antirretroviral.

\section{INTRODUCTION}

As previously described, HIV has tropism for T-cells that express CD4 and macrophages, which leads to a reduction in the number of lymphocyte cells responsible for recognizing antigens foreign to the organism. Drug therapy for those patients began in 1987 with the use of Zidovudine (AZT) ${ }^{1}$. In the mid-1990s, new drug classes such as protease and reverse transcriptase inhibitors have become available ${ }^{2}$.

Those drugs significantly suppress viral replication and make HIV-positive patients have less frequent clinical manifestations, which leads to a substantial improvement in prognostic and quality of life of infected persons. That enabled a change in the disease profile, which was culturally associated with death but that, as treatment advanced, acquired a chronic character ${ }^{3,4}$.

Although this treatment improves the morbidity rate and well-being of patients, its continuous use may cause severe metabolic alterations such as HIV-associated lipodystrophy (redistribution of body fat with peripheral lipoatrophy and central lipohypertrophy) alone or accompanied by hyperlipidemia, hyperglycemia, dyslipidemia, and insulin resistance ${ }^{5,6}$.

Lipoatrophy is characterized by a decrease in fat tissue in the face, particularly in the nasolabial folds, buttocks, and upper and lower limbs.
Lipohypertrophy, or lipomatosis, can occur in more than one region simultaneously and corresponds to the increase in central abdominal fat tissue and in the cervical back, gynecomastia, and enlarged breasts among women. The etiology of lipodystrophy in treated HIV infection is multifactorial7,8,9.

Insulin resistance is defined as a subnormal biological response to a given concentration of this hormone. Systemic inflammation associated with HIV infection might promote monocyte migration across the vascular endothelium, leading to an increased number of activated macrophages in fat. Cytokines and viral proteins can inhibit adipocyte differentiation as well as induce mitochondrial dysfunction and insulin resistance ${ }^{10}$.

Those disorders cause alterations in the patients' glucose metabolism and may pose significant cardiovascular risk. Moreover, studies have shown a reduction in the quality of life of patients due to lipodystrophy-associated body changes, which limits adherence to treatment. Better understanding the relation between lipodystrophy syndrome among HIV-positive patients and insulin resistance is of key importance to provide better quality of life to those persons.

With that in mind, the present study assessed whether HIV-positive patients with and without lipodystrophy syndrome in antiretroviral therapy had insulin resistance and the influence of the duration of antiretroviral use. 


\section{MATERIALS AND METHODS}

Site

The present descriptive, analytical, crosssectional study was carried out at the Clinics Hospital of the Medical School of Ribeirão Preto $(\mathrm{HC} /$ FMRP) and was analyzed and approved by the Committee of Research Ethics of the hospital and the Medical School of Ribeirão Preto (HCRP process no. 3900/2011).

Participants were recruited at the Special Unit for the Treatment of Infectious Diseases (Unidade Especial de Tratamento para Doenças Infecciosas - UETDI) of the Nutrition and Infectious Diseases Outpatient Clinic of the Clinics Hospital of the Medical School of Ribeirão Preto (HC-FMRP). For the control group, individuals were selected from different specialties of the Clinics Hospital who were found to be HIV-negative in a test performed for reasons other than the research while following the inclusion and exclusion criteria of the study.

\section{Study Group}

The study assessed 36 subjects of both sexes between 22 and 60 years old split into three groups:

1. Seropositive for HIV using ART with lipodystrophy syndrome $\left(\mathrm{HIV}^{+} \mathrm{LIPO}^{+}\right)$;

2. Seropositive for HIV using ART with no lipodystrophy syndrome ( $\left.\mathrm{HIV}^{+} \mathrm{LIPO}^{-}\right)$;

3. Seronegative for HIV and healthy (Control).

In order to be included in the HIV+LIPO+ group, the individual had to report loss and/or accumulation of fat in specific regions of the body, which was confirmed through a clinical examination according to the criteria by Sutinen J. and Yki-J ärvinen H. ${ }^{11}$.

Therefore, it was essential that at least one site showed lipoatrophy, i.e., visible loss of fat in peripheral regions (arms or legs) or face accompanied or not by lipohypertrophy, i.e., accumulation of fat in the abdominal region, dorsal gibbosity, or gynecomastia ${ }^{12}$.

\section{Anthropometric Evaluation}

Weight and height were measured according to Frisancho (1989). The body mass index (BMI) was calculated from the relation between the in- dividual's weight $(\mathrm{kg})$ divided by the square of the height $(\mathrm{m})$. Thus, the unit of measurement of the $\mathrm{BMI}$ is $\mathrm{kg} / \mathrm{m}^{2}$.

\section{Biochemical Evaluation}

The laboratory analyses of the biological material collected were performed at the MultiUser Laboratory of Nutrition and Metabolism of the Medical School of Ribeirão Preto using blood collected in the morning in $5 \mathrm{~mL}$ BD Vacutainer ${ }^{\circledR}$ SST ${ }^{\circledR}$ II Advance ${ }^{\circledR}$ tubes after $12 \mathrm{~h}$ of fasting.

After collection, the blood samples were centrifuged in a Universal $320 \mathrm{R}$ Hettich ${ }^{\circledR}$ centrifuge for $10 \mathrm{~min}$ at $23^{\circ} \mathrm{C}$ and $3,500 \mathrm{rpm}$. The sera obtained were stored at $-20^{\circ} \mathrm{C}$ until the analyses.

The biochemical tests performed in the present study aimed to assess glucose metabolism in the subjects. Fasting glycemia was determined by the colorimetric method using Labtest $\AA$ (Labtest Diagnóstico S. S., Lagoa Santa, Minas Gerais, Brazil) kits and a Molecular Devices ${ }^{\circledR}$ Spectro Max M5 device, while fasting insulinemia was determined by a commercial kit using solidphase chemiluminescence immunometric assay (IMMULITE ${ }^{\circledR}$, DPC, Los Angeles, California, USA).

\section{Calculating HOMA (Homeostatic Model Assessment)}

HOMA was calculated from the serum concentrations of glucose and insulin, which assessed insulin resistance. According to the guidelines of the Brazilian Diabetes Society, an insulin resistance diagnostic requires HOMA-IR > 4.65. HOMA is calculated using the formula: fasting glycemia $(\mathrm{mmol} / \mathrm{L}=\mathrm{mg} / \mathrm{dL} \div 18) \times$ fasting insulinemia $(\mu \mathrm{U} /$ $\mathrm{mL}) / 22.5$.

\section{RESULTS}

The 36 participants of the present study, 12 females and 24 males, were assigned to one of the three groups, with 12 participants in each group. The nutritional status assessment showed that all groups had average BMI below $24.9 \mathrm{~kg} /$ $\mathrm{m}^{2}$, i.e., within the limits to be classified as eutrophic.

The HIV+LIPO+ group had the highest mean age ( $46.7 \pm 8.9$ years). It also had the longest time of HIV infection, time under antiretroviral therapy, and highest $\mathrm{CD}^{+}{ }^{+}$cell count, with a difference 
$(p<0.05)$ in the first two variables compared to group HIV+LIPO.

All data presented above can be found in Table 1.

So that the biochemical profile of the groups in the present study could be known, the results of the biochemical analyses were represented as means and standard deviation for each group. An analysis of glycemic control markers shows a difference between groups $\mathrm{HIV}^{+} \mathrm{LIPO}^{+}$and Control for the values of insulin and HOMA-IR $(p<0.05)$, with the former having higher means (Table 2).

\section{DISCUSSION}

The present study investigated possible alterations in glucose metabolism by HIV infection, time of antiretroviral therapy, and presence or absence of lipodystrophy syndrome.
The groups of individuals infected with HIV were mostly male, in accordance with the statistical data of the Brazilian Ministry of Health of cases of HIV registered in the Information System on Diseases of Compulsory Declaration (Sistema de Informação de Agravos de Notificação - Sinan) between 2007 and 2015, which informs 61,904 cases among men and 31,331 among women ${ }^{1}$.

This study showed an association of longer antiretroviral therapy use with increased development of lipodystrophy syndrome in the $\mathrm{HIV}^{+} \mathrm{LIPO}^{+}$group. The extended use of ART is, therefore, related to a number of complications and metabolic disorders, including redistribution of body fat and lipodystrophy ${ }^{13,14}$. That shows the importance of continuously monitoring patients under antiretroviral therapy so that drug association can be adequated or even switched to other antiretroviral medications.

Table 1

Characteristics related to age group, anthropometric data, and HIV infection in the different groups of the study.

\begin{tabular}{|c|c|c|c|}
\hline Variables & $\begin{array}{c}\text { HI V+LI PO+ } \\
\text { Fem }(n=3) / \text { Male }(n=9)\end{array}$ & $\begin{array}{c}\text { HI V+LI PO- } \\
\text { Fem }(n=2) / \text { Male }(n=10)\end{array}$ & $\begin{array}{c}\text { CONTROL } \\
\text { Fem }(n=7) / \operatorname{Male}(n=5)\end{array}$ \\
\hline & $($ Mean \pm SD) & $($ Mean \pm SD) & $($ Mean $\pm S D)$ \\
\hline Age (years) & $46.7 \pm 8.9$ & $37.9 \pm 9.0$ & $30.6 \pm 9.4$ \\
\hline Weight (kg) & $72.69 \pm 11.5$ & $72.85 \pm 17.66$ & $67.17 \pm 13.48$ \\
\hline Height (m) & $1.71 \pm 0.06$ & $1.72 \pm 0.1$ & $1.68 \pm 0.06$ \\
\hline BMI $\left(\mathrm{kg} / \mathrm{m}^{2}\right)$ & $24.83 \pm 3.27$ & $24.42 \pm 3.89$ & $23.88 \pm 4.22$ \\
\hline Time with HIV (years) & $14 \pm 5.46$ & $5.92 \pm 6.17$ & - \\
\hline Time in antiretroviral therapy (years) & $11.25 \pm 3.57$ & $4.32 \pm 3.24$ & - \\
\hline $\mathrm{CD}^{+}\left(\right.$cells $\left./ \mathrm{mm}^{3}\right)$ & $561.67 \pm 257.25$ & $539.83 \pm 239.66$ & - \\
\hline Viral load (copies/mL) & Undetected & Undetected & - \\
\hline
\end{tabular}

Note: Kruskal-Wallis test. The values are expressed as means \pm standard deviation. Abbreviations: BMI = body mass index; Undetected viral load: $<50$ copies $/ \mathrm{mL}$.

Table 2

Biochemical profile of the groups studied represented by means and standard deviation.

\begin{tabular}{|c|c|c|c|}
\hline TESTS & $\mathrm{HIV}^{+} \mathrm{LIPO}^{+}$ & $\mathrm{HIV}^{+} \mathrm{LIPO}^{-}$ & CONTROL \\
\hline & (Mean $\pm S D)$ & $($ Mean $\pm S D)$ & $($ Mean $\pm S D)$ \\
\hline Glycemia $(\mathrm{mg} / \mathrm{dL})$ & $102.27 \pm 30.03$ & $96.41 \pm 16.05$ & $84.12 \pm 6.07$ \\
\hline Insulin $(\mu \mathrm{U} / \mathrm{mL})$ & $6 \pm 3.69 *$ & $3.3 \pm 3.36$ & $2.09 \pm 3.28 *$ \\
\hline HOMA-IR & $1.61 \pm 1.17 *$ & $0.79 \pm 0.87$ & $0.46 \pm 0.72 *$ \\
\hline
\end{tabular}

Note: Kruskal-Wallis test. The values are expressed as means \pm standard deviation. The presence of an * represents $p<0.05$. Abbreviations: HOMA-IR: homeostasis model assessment - insulin resistance 
HOMA-IR was statistically significant when the $\mathrm{HIV}^{+} \mathrm{LIPO}^{+}$group was compared with the Control group (Table 2), which was expected given that insulin resistance is an important complication associated with lipodystrophy. Insulin resistance was not significantly different when the HIV+LIPO- group was compared with the $\mathrm{HIV}^{+} \mathrm{LIPO}^{+}$and Control groups. Our results support previous investigation by Deminice $R$. et al. (2013), which showed significant differences only between the control group and $\mathrm{HIV}^{+} \mathrm{LIPO}^{+15}$.

Even though significant differences in insulin resistance were not found in other groups of this study, the glucose metabolism of all HIV-positive patients must be controlled in order to prevent lipodystrophy and its complications. In addition to the constant monitoring of the HIV patient, early lifestyle adjustments are necessary, such as in diet and physical activity.

It can be seen that the presence of insulin resistance has a positive correlation with antiretroviral therapy initiation (Table 3). Such association matches the literature, where it is reported by $8-10 \%$ of the patients with HIV, an alteration in glucose metabolism seen as early as a few months after drug therapy is initiated ${ }^{16,17,18}$.

Also using HOMA-IR values, another study found statistical differences among patients under antiretroviral therapy, with higher glycemia levels, larger area under the curve of glycemia variation, and higher values of fasting insulinemia and HOMA-IR compared with patients not in antiretroviral therapy ${ }^{19}$.

The adherence of HIV-positive patients to antiretroviral therapy leads to improvements in clinical results, may control the advance of the

\section{Table 3}

Pearson correlation for HIV-positive patients regarding the duration of ARV use

\begin{tabular}{ll}
\hline TESTS & value \\
\hline Glycemia $(\mathrm{mg} / \mathrm{dL})$ & 0.32 \\
Insulin $(\mu \mathrm{U} / \mathrm{mL})$ & 0.36 \\
HOMA-IR & $0.41^{*}$ \\
Time with HIV (years) & $0.83^{*}$ \\
\hline
\end{tabular}

disease, and, thus, tends to lower the mortality rate. That would result in longer life expectancy since the quality of life of the patients improves.

Nonetheless, the use of antiretroviral therapy may be accompanied by several impacts on health, potentializing some metabolic syndromes such as systemic arterial hypertension, causing increased risk of the development of cardiovascular diseases, besides abnormal body fat distribution.

Insulin resistance is also shown to increase, whose effects range from alterations in glucose metabolism to the development of type- 2 diabetes mellitus, as reported in the literature ${ }^{8,20}$.

In face of the positive relation between the time using antiretroviral therapy and time with HIV and changes in glucose metabolism, evidence suggests that, despite the improvement in life expectancy, those alterations are persistent and require care during treatment.

There are limiting aspects of this study to be signaled. Besides antiretroviral therapy duration, the duration of infection by HIV is also positively related to changes in glucose metabolism. Another limitation is the sensitivity of the resistance marker to HOMA. In addition, volunteers diagnosed with pre-diabetes and type- 2 diabetes according to parameters by the Brazilian Diabetes Society 21 were not excluded from the study groups.

\section{CONCLUSION}

The time of HIV infection, the time using antiretroviral therapy, and the presence or absence of lipodystrophy negatively impact glucose metabolism and lead to an increase in peripheral insulin resistance, glycemia, and plasma insulin levels.

Such increase is even more pronounced in HIV-positive individuals using antiretroviral therapy and showing lipodystrophy, while HIVpositive individuals under antiretroviral therapy with no lipodystrophy also show this increase, but more mildly and with no statistical significance for the group of infected patients. 


\section{REFERENCES}

1. Ministério da Saúde (Brasil). Secretaria de Vigilância em Saúde. Departamento de DST, Aids e Hepatites Virais. Boletim Epidemiológico - Aids e DST. Brasília, 2015.

2. Arts EJ, Hazuda DJ. HIV-1 antiretroviral drug therapy. Cold Spring Harbor Perspect Med. April, 2012.

3. Nascimento FO. Tratamento Antirretroviral. Revista Uniplac, 2016; 4: ํo 1.

4. Garbin CAS, Gatto RCJ Garbin AJI. Adesão à terapia antirretroviral em pacientes HIV soropositivos no Brasil: uma revisão da literatura. Arch Health Invest. 2017; 6: 65-70. http://dx.doi.org/10.21270/ archi.v6i2.1787

5. Alves TC, de Moraes C, dos Santos AP, Venturini ACR, de Carvalho Santana R, Navarro AM, Machado DRL. Chance aumentada de síndrome metabólica em mulheres vivendo com HIV/AIDS e Síndrome da Lipodistrofia. Rev Medicina (Ribeirão Preto. Online), 2016;49:421-8.

6. Guzman N, Al Aboud AK. HIV-associated Lipodystrophy. StatPearls [Internet]. Treasure Island, 2018.

7. Santos AP, Navarro AM, Schwingel A, Alves TC, Abdalla PP, et al. Lipodystrophy diagnosis in people living with HIV/AIDS: prediction and validation of sex-specific anthropometric models. BMC Public Health. 2018; 18: 806. doi: [10.1186/s12889-018-5707-z]

8. Beraldo RA, Santos AP, Guimarães MP, Vassimon HS, Paula FJA, Machado DRL, et al. Redistribuição de gordura corporal e alterações no metabolismo de lipídeos e glicose em pessoas vivendo com HIV/ AIDS. Rev Bras Epidemiol. 2017; 20:526-36.

9. Lake JE, Stanley TL, Apovian CM, Bhasin S, Brown TT, Capeau J, et al. Practical Review of Recognition and Management of Obesity and Lipohypertrophy in Human Immunodeficiency Virus Infection. Clin Infect Dis. 2017;64:1422-9. doi: 10.1093/cid/ cix178.

10. Caron-Debarle M, Lagathu C, Boccara F, Vigouroux C, Capeau J. HIV-associated lipodystrophy: from fat injury to premature aging. Trends Mol Med. 2010;16:218-29. doi: 10.1016/ j.molmed.2010.03.002.

11. Sutinen J, Yki-Järvinen $\mathrm{H}$. Increased resting energy expenditure, fat oxidation, and food intake in patients with highly active antiretroviral ther apy-associated lipodystrophy. Am J Physiol Endocrinol Metab. 2007; 292: E687-92.
12. Obirikorang C, Quaye L, Osei-Yeboah J, Odame EA, Asare I. Prevalence of metabolic syndrome among HIV-infected patients in Ghana: A cross-sectional study. Niger Med J. 2016; 57: 86-90.

13. Abrahams Z, Maartens G, Levitt N, Dave J. Anthropometric definitions for antiretroviral-associated lipodystrophy derived from a longitudinal South African cohort with serial dual-energy X-ray absorptiometry measurements. Int J STD AIDS. 2018;29:1194-203.

14. Valente AMM, Reis AF, Machado DM, Succi RCM, Chacra AR. Alterações Metabólicas da Síndrome Lipodistrófica do HIV. Arq Bras Endocrinol Metab. 2005; 49:871-81.

15. Deminice R, Vassimon HS, Machado AA, Paula FJA, Monteiro JP, Jordão AA. Plasma homocysteine levels in HIV-infected men with and without lipodystrophy. Nutrition, 2013.

16. Rodovalho AG, Tristão FN, Galvão LLC, Rodovalho RG, Torunsky RC, Lucchese R.Associação entre o uso de antirretrovirais no tratamento para HIV e alterações físicas e metabólicas. Blucher Education Proceedings, 2016

17. Kramerll AS, Lazzarotto AR, Sprinz E, Manfroi WC. Alterações metabólicas, terapia antirretroviral e doença cardiovascular em idosos portadores de HIV. Arq. bras. Cardiol., São Paulo, 2009

18. Noor MA, Flint OP, Maa JF, Parker RA. Effects of atazanavir/ritonavir and lopinavir/ ritonavir on glucose uptake and insulin sensitivity: demonstrable differences in vitro and clinically. AIDS, 2006.

19. Guimarães MMM, Greco DB, Júnior ARO, Penido MG, Machado LJC. Distribuição da gordura corporal e perfis lipídico e glicêmico de pacientes infectados pelo HIV. Arq. bras. endocrinol. metab. São Paulo, 2007.

20. Idiculla J, Ravindra'n GD, D'Souza J, Singh G, Furrugh S.Diabetes mellitus, insulin resistance, and metabolic syndrome in HIV-positive patients in South India. Int J Gen Med, 2011.

21. Sociedade Brasileira de Diabetes. Diretriz da Sociedade Brasileira de Diabetes 2017-2018. Editora Clannad, 2017. 